\title{
Onlangse konsepte in teksuitleg en hulle konsekwensies vir die (gereformeerde) teologie
}

\author{
F.E. Deist \\ Dept. Ou Nabye Oosterse Studie \\ Universiteit van Stellenbosch \\ STELLENBOSCH
}

\begin{abstract}
Over the past century Old Testament exegesis closely followed developments in the fields of philosophy and theory of literature (e.g. romanicism, historism, phenomenology, siructuralism) and has since the early sevenues of this century been challenged by new approaches to textual interpretation. such as reception criticism, ideology criticism and deconsiruction, as well as by developments in texinal criticism. The article seeks to explore the positive implications of these developments for the interpretation of the Old Testament and, more specifically, for reformed theology.
\end{abstract}

\section{Inleidend}

Die gereforneerde teologie maak daarop aanspraak dat dit 'n Skrifgefundeerde teologie is - gevolglik speel eksegese 'n belangrike rol in dié teologie. Ontwikkelinge op die gebied van teksinterpretasie en tekskritiek die afgelope paar dekades problematiseer egter die tradisionele trio van Bybel-eksegese-teologie wat die 'Bybelsheid' van die gereformeerde teologie gewaarborg het. Dit is die doel van hierdie artikel om eerstens 'n breë oorsig te gee oor tendense op die gebied van teksinterpretasie in die algemene literatuurwetenskap en die tekskritiek van die Ou Testament (paragrawe 2-3) en om dan (paragraaf 4) 'n paar van die implikasies van dié insigte vir die gereformeerde teologie aan te stip. Die bedoeling is nie om finale konklusies te trek nie, maar bloot om die gereformeerde gesprek oor die Skrif op 'n heel beskeie manier te dien.

\section{2. 'n Dubbele verskuiwing in teksuitleg}

\subsection{Van historisme na fenomenologie}

Die histories-filologiese en histories-kritiese benadering tot teksinterpretasie, met sy romantiese belangstelling in die outeur van 'n teks en sy historiese omstandighede (vgl. Hermand, 1971:1-3), en daannee in die sogenaamde wêreld agter 
die teks, was onder meer 'n reaksie op die rasionalistiese en spekulatiewe opvattings van die agtiende en vroeë negentiende eeu (vgl. Deist, 1987). Teen die middel van die twintigste eeu het die histories-evolusionistiese metode van interpretasie egter ongewild begin raak. Spitzer (1948:2) sê byvoorbeeld van sy eie opleiding in die histories-kritiese literatuurwetenskap van daardie tyd: "[W]e were never allowed to contemplate a phenomenon in its quiet being, to look into its face: we always looked at its neighbours or at its predecessors". Ook eksegete het hulle misnoeë gelug oor die feit dat die literêre kritiek, wat eksegete in staat moes stel om agter die teks te kan 'inkyk', die samehang van die Bybelse teks versteur en verhoed het dat die finaal geredigeerde teks self aan die orde kom (Muilenberg, 1969; Greenwood, 1970; Deist, 1973).

Gevolglik is daar sedert die middel van die twintigste eeu oor 'n breë front afskeid geneem van atomisme en histories-evolusionistiese verklaringsraamwerke: in die wysbegeerte het fenomenologie en eksistensiële filosofie inslag gevind, in die sielkunde en kunste word die Gestalt-teorie populêr en in die literatuurwetenskap die morfologiese metode (Maren-Grisebach, 1970:39-79). Ook Bybelwetenskaplikes het, saam met literatuurwetenskaplikes, al hoe meer begin belangstel in die vraag: wat sê 'n literêre teks self, dit wil sê, ongeag sy familiegeskiedenis? Met die belangstelling nou in die sogenaamde wêreld in die teks (Weiss, 1961) het die era van die strukturalistiese en struktuuranalitiese eksegetiese metodes aangebreek (Fokkema \& Ibsch, 1979:50-80). Dit is interessant om te sien dat, terwyl gereformeerde eksegete in Suid-Afrika oorwegend nie erg gehad het aan die histories-kritiese aanpak nie (vgl. Verhoef, 1973:45-60; Roberts, 1981:191; Prinsloo, 1988; maar ook Van Zyl, 1972; 1973), hulle sedert die laat sestigerjare voluit deelgeneem het aan struktuuranalitiese en diskoersanalitiese eksegese. Dié aanvaarding van die strukturele teksinterpretasie het egter nie noodwendig op metodologiese oorwegings berus nie. Vir sommige, soos vir myself (Deist, 1973: 7881 ), was die 'teksimmanente' benadering eerder 'n welkome uitkoms uit die probleme wat die historiese benadering vir die ortodokse gerefonneerde Skrifbeskouing meegebring het. 1

\subsection{Van fenomenologie na kontekstualiteit}

Etlike van die veronderstellings waarop die 'immanente' benadering tot teksuitleg berus het, sou egter mettertyd onder skerp kritiek kom. Van die belangrikste aannames was eerstens dat 'n teks (bv. die Bybelse teks) 'n outonome werk is, onafhanklik van sy oorspronge én sy lesers en slegs onderworpe aan die wetmatigheid van 'literatuur' (vgl. Hermand, 1971:6-8; Fokkema, \& Ibsch, 1979:4-7; Ingarden, 1968:6-13; Wellek \& Warren, 1968:158; Wimsatt, 1970). 'n Tweede aanname was dat 'n teks se betekenis bloot deur sy eie gestruktureerdheid gegenereer word (vgl. Ingarden, 1968:21-35; Scholes, 1974:10). 'n Derde aanname

Vir 'n volicdige uiteensetting van die problecm, kyk hoofstuk 5 van Deist. 1994 
was dat interpreteerders, as hulle maar net hulle eie vooroordele en voorkennis oor die teks opskurt en oor die korrekte gereedskap beskik om in die gestruktureerdheid van die teks in te dring, daardie betekenis op 'n objektiewe manier uit die teks kan aflees en weergee (vgl. Roberts, 1975:201). Miskien was dit juis die aanspraak op objektiwiteit wat strukturele metodes gewild gemaak het by gereformeerde eksegete: dit het die gerustheid geskep dat 'n mens presies en geverifieerd kan nasê wat in die gesagvolle teks self staan.

Twee ontwikkelings het egter hierdie geloof in objektiwiteit sterk onder verdenking gebring. Aan die een kant was daar die wetenskapsteoretiese bydraes van mense soos Feyerabend, Toulınin, Laudan en Kuhn (vgl. Losee, 1980:189-201) wat geargumenteer het dat rasionaliteit nie objektiwiteit kan waarborg nie, aangesien kriteria vir rasionaliteit onder andere kultuurbepaald is. Aan die ander kant was daar 'n groeiende misnoeë met die immanente metodes, omdat dié benadering tekste in die algemeen van hulle kultuurhistoriese en Bybeltekste in besonder van hulle godsdienshistoriese bedding losgesny het. In die Bybelwetenskap was die gevolg hiervan onder meer dat die pad gebaan is vir 'n a-historiese en dus onkritiese, fundamentalistiese Skrifgebruik, wat wesensvreemd is aan die gereformeerde Skrifbeskouing (vgl. Deist, 1989b). Terselfdertyd het die 'objektivering' van die Bybel dit van sy lesers vervreem. Gevolglik is daar sedert die laat sewentigerjare weer emstig gesoek na weë om die kontekstualiteit/ historisiteit van die tekste én hulle uitleggers te verreken (vgl. Veeser, 1989; Lategan \& Vorster, 1985).

\section{Nuwere (hermeneutiese) konsepte in teksuitleg}

\subsection{Die leser as aktiewe deelnemer in die eksegetiese proses}

Sedert die sewentigerjare het die algemene literatuurwetenskap sterker begin fokus op die sogenaamde wêreld voor die teks en sedert die tagtigerjare het die Bybelwetenskappe hierdie pad saam met die literatuurwetenskap begin loop (vgl. Lategan 1987; Snyman 1991; Wessels 1993).

Studies soos dié van Gadamer (1960), Jauss (1970) en Iser (1970) oor die bydrae van lesers en leestradisies tot die 'betekenis' van tekste het getoon dat lesers se voorkennis en die leestradisie wat hulle onderskryf (in die geval van die Bybel byvoorbeeld fundamentalisme, gereformeerd, liberaal, charismaties) by hulle bepaalde verwagtings wek omtrent die betekenis van 'n Bybelse teks (vgl. Snyman, 1992a:73-76). Die indrukke wat tydens die leesproses versamel word, word as 't ware in die leggersisteme van die leestradisie en die lesersverwagting gesorteer en geliasseer. Maar daarmee word die teks se betekenis onvermydelik, maar ook onherroeplik, verander. Kwantum-fisici sou sê: "The observer disturbs the object of his observation, and that as a matter of principle, namely one which is fundamentally epistemological" (Rund, 1962:5; vgl. ook Heisenberg, 1969:146- 
147). Dis asof elke leser 'n reeds beskrewe manuskrip is waaroor die letters van die gelese teks geskryf word, sodat daar tydens die lees en uitleg van die teks 'n palimpses ontstaan waarin albei tekste (die gelese teks en die leser van die teks) sigbaar is (Fokkema \& Ibsch, 1979:136-164).

Teksbetekenis, so word geargumenteer, is nie 'n blote statiese gegewene of iets wat 'n teks objektief 'het' nie, maar iets wat in die leesproses gemaak word of tot stand kom. En omdat verskillende lesers elkeen self ' $n$ (tradisie-beskrewe) teks is wat met die gelese teks in interaksie gaan, is die betekenis wat in die eksegetiese proses tot stand kom die produk van die interaksie tussen die teks en sy (unieke) leser of lesersgemeenskap. Met verwysing na De Bono se konsep van aktiewe en passiewe informasiesisteme kan 'n mens dié insig ook soos volg verwoord (De Bono, 1987:104):

In dealing with thinking we have always assumed that we are dealing with a passive information system ... You make marks on paper and they stay there. You make marks on a magnetic disc and they stay there ... The very notion of 'analysis' and 'truth' depends on such an information universe. But perception and creativity cannot be understood in such a universe .. There is another type of information universe. This is the active information surface. It is a surface on which information can organise itself into patterns. It is a self-organising system.

Die inligting waarmee ' $n$ leser na 'n teks toe kom, is nie bloot dormant nie en daarom nie regtig 'opskortbaar', soos die rein fenomenologiese en strukturele interpretasie aanvaar het nie. En omdat die inligting wat uit die teks na die leser toe kom in interaksie kom met die voorkennis en interpretasietradisie van die leser, is interpretasie ' $\mathrm{n}$ kreatiewe gebeure. Fokkema en Ibsch (1979:138) vat die essensie van resepsie-estetika soos volg saam:

Reception theory allows for historical and cultural relativism, since it is fundamentally convinced of the mutability of an object, also the literary work, within the historical process. Nevertheless it does not for that reason amount to a relapse into the historicism of the nineteenth century. It differs from that historicism in its renunciation of value-free research. The scholar's own epoch is not disqualified in favour of an attitude which prescribes that he creeps into the skin of an author of the past. One's own epoch is an essential element in the constitution of the aesthetic object ... On the other hand the element of historical relativism in reception theory prevents the indiscriminate appropriation of works from the past, an activity which ... in the final analysis leads to the designation of timelessness as the essential characteristic of literature.

Die klem op die leser het egter nie beteken dat die outeur (waarop histories-kritiese en histories-grammatiese eksegese gefokus het) en die struktuur van die teks (waarop close reading en diskoersanalise gebaseer is) daarmee 'agterhaal' of 
irrelevant geword het nie, ${ }^{2}$ maar bloot dat lesers as aktiewe deel van die interpretasieproses óók ernstig geneem word (vgl. Lategan, 1992:9-10 en die kritiek van McKnight, 1992:278 e.v. op Brimer, 1992).

Dit gaan egter nie maar net oor die invloed van 'n leser se teologiese interpretasietradisie op eksegese nie. Selfs die 'agtergrondskennis' of grammatikale/ literêre vaardighede van eksegete (wat vroeër die argumentbasis en waarborg was vir 'korrekte' teksinterpretasie) is uitgeken as konstruksies wat op grond van hedendaagse teorieë gemaak word oor destydse skrywers, hulle omstandighede en hulle tekste. So, byvoorbeeld, het die toepassing van alternatiewe antropologiese en sosiologiese modelle in historiografie die aanskyn van veral die vroeë geskiedenis van Israel dramaties verander. Ook die grammatikas aan die hand waarvan filologiese/diskoersanalitiese teksstudies gedoen word, is almal op die een of ander taalteorie gebaseer, sodat die geldigheid van die resulterende eksegese relatief is tot die aanvaarbaarheid van die onderliggende teoriee (vgl. Scholes, 1974:38). ${ }^{3}$ Daar is nie iets soos bruta facta nie. ${ }^{4}$ Trouens, as dit nie vir teorieë was nie, sou eksegete niks kon waarneem of sistematiseer nie. Einstein sou gesê het: "Erst die Theorie entscheidet darüber, was man beobachten kann" (Heisenberg, 1969:92).

\subsection{Ideologiekritiek en retoriek}

Dit was veral kennissosiologie (by name die kritiese teorie van die Frankfurtskool) wat eksegese op twee vlakke beinvloed het. Aan die een kant het die besef posgevat dat die tradisies en historiese milieu waarbinne die outeurs van Bybelse tekste geleef het, hulle nie onaangeraak gelaat het nie. Aan die ander kant is ingesien dat die ekonomiese posisie, sosiaal-politiese voorkeure en 'interesse' 5 van hedendaagse uitleggers van Bybelse tekste ' $n$ vername rol speel

2 By sommige rescpsie-cstete verdwỹn die teks as 'gespreksgenoot' totaal uit die prentjic en gaan dit bloot nog oor 'tcksgebruik' en 'teksprosesscring' (vgl bywoorboeld Wicnold. 1972: 184) By ander, byvoorbeeld Jauss, Iser en Mandelkow specl dic teks as historicse en strukturcle gegewe egter nog stoeds 'n belangrike rol

3 So berus Brockelmann (1956) se Hebrdısche Synıax op dic (cvolusionistics-) psigologistiesc taalbeskouing van Bühler, teruyl strukturalisticse grammatikas, soos die van Richter (1980) op 'n Saussuriaansc beskouing van taal as 'n sisteem van tekens gebascer is

4 Dié insig is natuurlik al minstens so oud soos Whewell se kentcoretiese geskrifte In dic woorde van Losec (1980:121): "Whewell conceded that there can be no such thing as a "pure fact' divorced from all idcas Any fact about an objcct or process necessarily involves the ideas of space, time, or number" Daarom het Whewell onderskei tussen 'teoric' as bewuste en 'feit' as onbewustc afleiding (inference) Juis dic onbewuste tcoreticse aard van 'fcite' maak hulle so gevaarlik

5 Vgl. Held (1980:255) vir 'n omsknwing van dic konsep interesse by Habermas. 
in hulle keuse van spesifieke metodes van uitleg en in hulle siening van die geldigheid al dan nie van eksegetiese resultate.

In die Ou-Testamentiese wetenskap is ideologiekritiek as interpretasiestrategie veral met verwysing na die sosiale wêrelde van die Bybelse outeurs toegepas (vgl. Carroll, 1990), hoewel die eksegeet nie buite perspektief gebly het nie (vgl. Deist, 1980; Carroll, 1991). Op dié manier is daar langs ander weë as die tradisionele onderskei tussen, byvoorbeeld, 'n priesterlike en 'n profetiese perspektief of ideologie: 6 omdat hulle normaalweg uit onderskeie lae van die samelewing gekom het en verskillende belange verteenwoordig het, het priesters anders na die werklikheid en die geskiedenis gekyk as profete. Priesters, as deel van die hoër middelklas en as mense wat belang gehad het by die bestaande (monargale) orde, was geneig om voorkeur te gee aan die status quo. Profete, daarenteen, was oorwegend nie deel van die 'establishment' nie en het vir verandering geveg (vgl. Van der Woude, 1985). Hierdie benadering het onder meer interessante lig gewerp op klassieke probleme in die Ou Testament. Met gebruikmaking van Festinger se konsep van kognitiewe dissonansie verklaar Carroll (1979) byvoorbeeld die voorkoms van onheils- én heilsprofesieë binne dieselfde profeteboek. Hanson (1979:211-228) verklaar weer die opkoms van apokaliptiek met behulp van 'n sosiologiese konflikmodel, terwyl Weinfeld (1972:225-232) aantoon dat veranderende sosiale omstandighede 'n dramatiese perspektiefverskuiwing binne dieselfde godsdienstige groep kan veroorsaak. Binne hierdie verstaansraamwerk word tekste nie meer as outonome entiteite 'teen' 'n bepaalde historiese 'agtergrond' geïnterpreteer nie, maar as deel van die diskoers van 'n bepaalde konteks (Montrose, 1989:18)

'n Bybelskrywer wat so 'n spesifieke ideologie steun en wat sy hoorders/lesers van sy siening wil oortuig, kies voorts ' $n$ bepaalde oorredingstrategie, oftewel retoriek. Die verrekening van hierdie oorredingstrategie oefen 'n bepalende invloed uit op eksegete se interpretasie en evaluering van die betekenis van Bybelse tekste. Terwyl retoriese analises van Nuwe-Testamentiese tekste redelik volop is - ook in Suid-Afrika - is dié soort studie in die Ou Testament nog relatief in sy kinderskoene (vgl. egter Duke, 1990). ${ }^{7}$

6 Vir 'n vollediger beskrywing van verskillende groepe wat by dic formasie van dic Ou Testament betrokke was, vgl Smith (1971).

7 Retoriese analise in die sin van die woord is cgter icts heel anders as wat Muilenberg (1969) en Greenwood (1970) onder rhetorical criticism verstaan het Rhetorical criticism in Muilenberg se sin van die woord is niks anders nie as close reading en het dus niks tc make met idcologiekritick nıc 


\subsection{Intertekstualiteit en dekonstruksie}

Die besef dat Bybelse tekste, hulle tyd, die gemeenskappe waarin hulle ontstaan het, hulle outeurs en redakteurs saam met hulle lesers deur die eeue heen een groot aktiewe infonnasiesisteem vonn waarvan die verskillende elemente mekaar oor en weer beinvloed on uiteindelik betekenis tot stand te bring, het ' $n$ feitlik outomatiese aansluiting gebied vir die invoer in die Ou-Testamentiese eksegetiese bedryf van die konsep intertekstualiteit en sekere basiese konsepte van dekonstruksie ${ }^{8}$ uit die nuwere literatuurwetenskap (vgl. Snyman, 1992b).

Een vall die basiese nosies van dekonstruksie is dat betekenis nooit 'aanwesig' is (om 'bepaal' te kan word) nie, maar gedurig uitgestel word. Soos die gebruiker van 'n verklarende woordeboek vir die betekenis van 'n spesifieke woord altyd na ander woorde verwys word, wat weer self met verwysing na verdere woorde verklaar word, sodat die gebruiker nooit werklik by 'die' betekenis van die oorspronklike woord uitkom nie, ondat die betekenis van die oorspronklike woord tussen dié van die ander lemmas 'gesaai' is, so is dit ook met die leser van 'n teks. Die woorde en konsepte van 'n teks verwys voortdurend na ander woorde en konsepte en bepaalde tekste na ander tekste (insluitend die 'teks' wat die uitlegger en sy tradisie uitmaak). Die Ou Testament praat byvoorbeeld nie altyd 'uit een mond' nie. Oor belangrike sowel as onbelangrike sake is daar verskil van mening tussen outeurs, ${ }^{9}$ sodat die verskillende geskrifte van die Ou Testament mekaar as 't ware voondurend 'ondermyn' om só 'n finale antwoord op vraagstukke uit te stel. Deurdat hedendaagse lesers by die spanning tussen die verskillende agtergronde van die Ou-Testamentiese outeurs en hulle literère konvensies (Miscall, 1990; Nielsen, 1990) en by die intene veelstemmigheid van die $\mathrm{Ou}$ Testament betrokke raak, word hulle self in die interpretasieproses ingetrek en word hulle eie tekstualiteit (ervaring, ideologie, geloof) dus in die spel gebring. Dis in hierdie voortdurende interaksie van teks en lesers dat kontingente, maar nietemin kontemporêre, betekenis geskep word ( $\mathrm{vgl}$. die studies van Detweiler, 1985; Gunn, 1987; Hunter, 1989; Van Wolde, 1990; Snyman, 1992b).

Hierdie benadering staan diametraal teenoor die veronderstellings onderliggend aan histories-kritiese, histories-grammatiese én struktuuranalitiese benaderings, wat telkens 'n definitiewe betekenis in tekste soek, en daag as 't ware die sekerhede van dié benaderings uit. Ernstig geneem kan die nuwere insigte daartoe bydra dat die kreatiewe inset van die leser tydens die interpretasie van die Bybel

8 Vir 'n kort, ingeligtc bespreking van dckonstruksic, ky.k Degenaar (1992)

9 Bywoorbecld: moes die Isracliete ivdens hulle woestynreis offer of nic? Het die mense God reeds in Set se tyd as Jahw'e geken. of het Hy Homself eers in dic tyd van Moses met die Naam bckend gemaak? Was dit dic land wat vir lsracl heilig was, of dic volk? Mag daar geen armes in Isracl gewees het nic, of sou daar altyd armes wees (Deut 15:4, I1)? Moct 'n mens 'n dwaas na sy sotheid antwoord of nic? (Spr. 26 4-5)? 
ronduit erken en selfs uitgelok word en dat die Ou-Testamentiese teks, in plaas daarvan om 'n veraf bron van 'objektiewe', en daarom passiewe informasie te wees, weer deel word van die lewende debat en teologisering (vgl. Wessels, 1993).

\subsection{Die konsepte 'teks van die Ou Testament' en 'die Ou Testament'}

Tekskritiek is vir lank slegs in 'n restouratiewe sin van die woord verstaan, dit wil sê, as die tegniek om die 'beste' of mees 'oorspronklike' teks van die Hebreeuse Bybel vas te stel, sodat die eksegese daaruit gedoen kan word (Verhoef, 1973:2124; Richter, 1971:22; Barth \& Steck, 1971:20). Gedurende die afgelope drie dekades (vgl. Barrick 1984) het dit egter duidelik geword dat die teks van die Ou Testament (waarop veral diskoersanalitiese en literêre studies hulle verlaat) nie 'n eenvormige entiteit is nie - selfs dat 'n mens kwalik van 'die' teks van die Ou Testament kan praat (vgl. Goshen-Gottstein, 1983).

Navorsing oor die verhouding tussen die Septuaginta en die Hebreeuse teks van die Ou Testament (vgl. Tov, 1978) en veral navorsing in Qumrangeskrifte (vgl. Tov, 1982) het aan die lig gebring dat die 'teks' van die Ou Testament tot in die Christelike era vloeibaar was. Verskillende kanons het in verskillende gemeenskappe gegeld, terwyl verskillende manuskripte van dieselfde boeke (bv. Samuel of Jeremia) in verskillende lokaliteite (bv. Egipte en Babilonië) gebruik is. Volgens die lokale teksteorie van die Harvardskool was daar in Egipte 'n ander kanon en teksvorm in omloop as in Palestina en in Palestina weer 'n ander teksvorm as in Babilonie. Die Massoretiese teks wat tans algemeen as basisteks vir eksegese gebruik word, is gevolglik maar één resensie van die Babiloniese versie van die boeke van die Ou Testament. Dit kan daarom nie sonder meer met die teks van die Ou Testament' gelykgestel word nie (vgl. Deist, 1989a). Tekskritiese navorsing het gewys dat 'die teks van die Ou Testament' inderdaad - om by die vorige paragraaf aan te sluit - 'n fisiese stel interlekste is (bv. Hebreeuse manuskripte, Dooie See-tekste, resensies van die Ou Grieks, ensovoorts).

Eksegete van die 'Ou Testament' behoort dus naas die Hebreeuse teks van die Biblia Hebraica Stuttgartensia ook gebruik te maak van tekste soos die Dooie See-rolle, die LXX, die Peshitta en die Vulgaat. Ons het, anders as wat dikwels sonder meer aanvaar word, in die Biblia Hebraica Stultgartensia nie 'die finale' teks van die Ou Testament in ons hand nie (vgl. Deist, 1992), maar bloot één van die baie tekste van die Ou Testament. 


\section{Enkele konsekwensies van die nuwere konsepte}

\subsection{Dic Ou Testament}

As 'n mens die insigte van die nuwere tekskritiek aanvaar, verwys die konsep 'Ou Testament' (oftewel 'die ou verbond') nie na 'n teks nie, maar na 'n (Christelike) teologiese konsep, oftewel 'n hermeneutiese of geloofsingesteldheid teenoor die voor-Christelike Israelities-Joodse tradisie. Daardie tradisie, waaraan die Christelike kerk 'n eie interpretasie geheg het, word weerspieël in 'n veelvuldigheid van tekste, wat daarom almal in die spel moet kom as 'Ou-Testamentiese' eksegese bedryf word. 'n Mens sou dus kwalik slegs van die Massoretiese teks kan gebruik maak vir die eksegese van die Ou Testament en kwalik ook 'n teologie van die 'Ou Testament' bloot op grond van die Massoretiese teks kan skryf. Hierdie insigte het natururlik ook belangrike implikasies vir die gangbare identifikasie van die Ou-Testamenties kanon met die Massoretiese teks (kyk Deist, 1992).

\subsection{Teksbetekenis}

As 'n mens die nuwere resepsie-estetiese, neo-historistiese en dekonstruksie-opvattings oor tekstualiteit aanvaar, is dit minstens problematies om van 'die betekenis' van 'n spesifieke teks te praat. Volgens vroeëre opvattings was die Bybelse teks as ' $\mathrm{I}$ ware 'n reservoir van betekenis, terwyl die eksegetiese metodes die krane was wat daardie betekenis objektief kon 'tap'. Volgens die nuwere literatuurwetenskap is daardie 'krane' egter nie net aan een reservoir (die teks) gekoppel nie, maar aan 'n verskeidenheid van reservoirs, waaronder

* verskillende reservoirs waarin 'n verskeidenheid tekstradisies gestoor is,

* verskillende reservoirs waarin die verskillende ideologieë van die antieke outeurs gestoor word,

* die reservoirs van die lang geskiedenis van die interpretasie van die Ou Testament, ell

* die verskeidenheid moderne reservoirs van eksegete se historisiteit, terwyl die krane self (die eksegetiese metodes) nie steriel is nie

As teksbetekenis dan nie iets staties is wat objektief 'beskikbaar' is nie, maar die produk is van 'n bevrugtende interaksie tussen die tekstualiteit van die teks se outeur, van die teks self én van die eksegeet en sy/haar metodes, gee hierdie 'konsepsie' geboorte aan 'n nuwe indiwidu wat genetiese eienskappe van sowel die vader (bv. die eksegeet se tekstualiteit) as die moeder (bv. die tekstualiteit van die teks) vertoon. ${ }^{10}$ En as diè insig geldig is, is die betekenis wat aan 'n teks toe-

10 Eicnaardig genoeg, het selfs daardic teoloe wat sterk gestaan het op dic bloot reseptieuc aard van cksegese en klem gelê het op objektiwiteit, nog alțd gesê dat preke gemaak word, 
geskryf word, kontingent en sal daar op teologiese terrein veel groter toleransie moet wees om ruimte te maak vir verskillende eksegete se historisiteit en die interpretasies wat daaruit gebore word.

\subsection{Teksinterpretasie en waarheid}

Seker die ingrypendste konsekwensie van nuwere eksegetiese en hermeneutiese konsepte is dat dit die klassieke, oftewel ortodoks-gerefonneerde, leerstellige konsep van 'waarheid' as ' $n$ stel rasionele en objektiewe sekerhede bevraagteken. En indien die nuwere konsepte geldigheid het, mag teoloë nie hulle oë daarvoor sluit nie. Inteendeel, dan behoort hulle selfkrities te kyk na die houdbaarheid van die waarheidsdefinisies van hulle tradisie.

Die idee van die historisiteit van die teks én die leser, en daarmee die erkenning van die kontingentheid en relatiwiteit van albei, hoef myns insiens nie 'n Tillichiaanse shaking of the foundations vir die gereformeerde teologie te wees nie: in die eerste plek ondat die erkenning van relatiwiteit nie vanselfsprekend skeptisisme impliseer nie (vgl. Van Niekerk, 1992:125-238). En tweedens, omdat die waarheid waaroor dit in die Bybel gaan, nie uitgelewer is aan die relativerende gevolge wat dié nuwe konsepte vir proposisionele waarheid het nie.

In die Bybelse sin van die woord, sou ek wou argumenteer, is 'waarheid' nie 'n denksisteem of ' $n$ stel proposisies of selfs belydenisse nie, maar 'n relasie met God, 'n relasie wat, waar dit ook al tot stand kom, telkens 'n kontingente vleeswording van die waarheid behels. As God deur die Heilige Gees 'in' ' $n$ mens 'woning maak', soos die Bybelse metafoor dit treffend formuleer, word die goddelike waarheid opnuut 'n kontingente waarheid, die waarheid in die mond van ' $n$ getuie. As dit korrek is, het waarheid in Bybelse sin meer met egtheid en 'n (historiese) ooreenstemming tussen geloofswoorde en geloofswerke te make as met (abstrakte en tydlose) proposisionele waarhede. Dis eers wanneer die geloofsgetuienis as teologie gefonnuleer word dat daardie fonnulerings aanspraak maak op universele geldigheid en daarmee aan die filosofiese waarheidskritiek onderwerp word." Wat dus in die gedrang is, is nie die waarheid waaroor die Bybel getuig nie, maar menslike formulerings van die waarheid (dogmas).

en daarmec geimplisecr dat interpretasic ' $n$ kreaticue proses is. Dic ou onderskeid tussen interpretasie en toepassing was 'n akademicse onderskeid, aangesien dit inderwaarheid 'n gelyktydige proses is.

11 Hansson (1992:167) maak 'n onderskeid tussen "meaning as act" en "meaning as object". wat mutatis mutandis ook hier van tocpassing is. Wat sy van betckenis sê, kan ook van waarheid geld: "[Mcssages] are sets of cues rather than complete sets of meaningful information. because receivers have limited information processing capacitics" Handelinge wat dic egtheid van dic waarheid weerspiecl, is $\infty \mathrm{k}$ sulke 'sporc' van waarheid, omdat mense nie dic kapasiteit het om die totaliteit meteens te leef of te sê nie 
As 'n mens die konsepte van intertekstualiteit en kreatiewe lesersbetrokkenheid erken en in die eksegetiese proses integreer, sal dit wat as eksegese geproduseer word beslis veel meer relatief wees as wat eksegete vroeër gemeen het om deur die rigiede toepassing van 'n eksegetiese apparaat te bereik. Maar so sal daar weer ruimte geskep kan word vir die Gees van God om die eksegeet se eie tekstualiteit saam met dié van duisende gelowiges voor hom in te span om iets vars in die kontinuum van uitleg tot stand te bring. En in dié nuwe uitleg sal die 'genetiese eienskappe' van die Bybelse tekste duidelik herkenbaar wees, maar ook die 'inset' van die eksegeet se tradisie en sy/haar historisiteit. Juis deur die veelvuldigheid van kerklike 'intertekste' waarbinne die Bybelse tekste resoneer, kan die veelkleurige genade van God telkens in ander omstandighede in 'n ander gedaante vlees word.

Die konsekwensie hiervan is egter dat die Bybel as magswapen uit eksegete en teoloë se hande geneem word om 'n blote wegwyser na die Waarheid te word, oftewel 'n verskeidenheid geskrifte wat weg van hulleself af wys na die Persoon oor wie hulle getuig. Die feit dat die hedendaagse tekswetenskap die vermeende 'vaste grond' onder eksegete uitgehaal het, mag daartoe bydra dat eksegete en teoloè tot op die vaste grond kan tuimel: die bewuste geloofsverhouding met die God oor wie die Bybelse geskrifte dit het. En dit sou goed gereformeerd wees.

\section{Bibliografie}

BARRICK, W.D 1984. Current Trends and Tensions in Old Testament Textual Criticism The Bible Translator, 35:301-308.

BARTH, H \& STECK, O.H 1971. Exegese des Alten Testaments Leitfaden der Methodik Neukirchen : Neukirchener Verlag

BRIMER, A 1992. Reception: a South African Experience (In Lategan, B C, ed. The Reader and Beyond. (HSRC Series in Methodology). Pretoria : HSRC p. 29-40.)

BROCKELMANN, C 1956. Hebraische Syntax. Neukirchen: Buchhandlung Erziehungsverein.

CARROLL. R P 1979. When Prophecy Failed: Reactions and Responses to Failure in the Old Testament Prophetic Tradition. London : SCM Press

CARROLL, R P. 1990. Ideology (In Coggins, R J \& Houlden, J.L. ed. A Dictionary of Biblical Interpretation London SCM p 309-311.)

CARROLL, RP. 1991. Wolf in the Sheepfold. The Bible as a Problem for Christianity. London SPCK

DE BONO, E 1987. Letters to Thinkers Further Thoughts on Lateral Thinking London Penguin

DEGENAAR, J 1992. Deconstruction - The Celebration of Language (In Lategan, B C., ed. The Reader and Beyond (HSRC Series in Methodology) Pretoria : HSRC. p. 87. 212.)

DEIST, FE. 1973. Ou-Testamentiese eksegese en Algemene Literatuurwetenskap. Ned. Teologiese Tydskrif. 14:75-81

DEIST, FE 1980 Idealistic Theologiegeschichte, Ideology Critique and the Dating of Prophetic Oracles of Salvation Ou-Testamentiese Werkgemeenskap van Suid-Afrika, 22 \& 23:53-78 
DEIST, F.E 1983. Bibelinterpretation und/als Ideologiekritik Old Testamem Essans, 126 48.

DEIST, F.E 1987. Relatiwisme en absolutisme: Kan dit oorkom word? Oor 'Bybelse' en 'Dogmatiese' teologie. (In Prinsloo, W.S \& Vosloo, W red Ou Testament teologie: gister, vandag en môre. Kaapstad : NG Kerk-Uitgewers p. 1-17.)

DEIST, FE. 1989a. Is die Massoretiese Teks die Ou Testament? Skrif en Kerk, 10:9-20

DEIST, F.E. $1989 \mathrm{~b}$ Fundamentalisme - 'n Gereformeerde beoordeling. Theologia Evangelica, 22(2): 2-8.

DEIST, F E. 1992 'Canonical Criticism', Reformed Theology and Developments in the Textual Criticism of the First Testament, Journal of Northwest Semitic Lamgrages, 18:3747.

DEIST, F E. [1994]. Honderd en vyftig jaar Bybeluitleg in die Nederduitse Gereformeerde Kerk (1840-1990). Pretoria : RGN

DETWEILER R 1985. What is a Sacred Text? Semeia, 31:213-230

DUKE, R K 1990. The Persuasive Appeal of the Chronicler A Rhetorical Analysis. New York: Almond

FOKKEMA, D \& IBSCH, E 1979 Theories of Literature in the Twentieth Century London : C. Hurst \& Co

GADAMER, H-G 1960. Wahrheit und Methode Grundzüge einer philosophischen Hermeneutik. Túbingen : J.C.B Mohr.

GOSHEN-GOTTSTEIN, M.H 1983. The Textual Criticism of the Old Testament: Rise, Decline and Rebirth. Journal of Biblical Literature, 102:368-380.

GREENWOOD, D Rhetorical Criticism and Formgeschichte: Some Methodological Considerations. Journal of Biblical Lilerature, 89:418-426.

GUNN, D M 1987. New Directions in the Study of Biblical Hebrew Narrative. Journal for the Study of the Old Testamem, 39:65-75.

HANSON, P D 1979. The Dawn of Apocalyptic The Historical and Sociological Roots of Jewish Apocalyptic Eschatology. 2nd ed. Philadelphia : Fortress Press

HANSSON, D 1992 Receiving Testimony: To Believe or not to Believe? (In Lategan, B C., ed. The Reader and Beyond. (HSRC Series in Methodology.) Pretoria HSRC p 163186.)

HELD, D 1980. Introduction to Critical Theory. London : Hutchinson

HEISENBERG, W 1969. Der Teil und das Ganze Gesprache im Umkreis der Atomphysik München : Piper Verlag

HERMAND, J 1971. Literaturwissenschaft und Kunswissenschaft Stuttgart: J B. Metzlerische Verlagsanstalt.

HUNTER, J.H. 1989. The Irony of Meaning: Intertextuality in Hebrew Poetical Texts . $/$ ournal of Semitics, $1: 229-243$

INGARDEN, R 1968 Vom Erkennen des literarischen Kunstwerks. Tübingen Max Niemeyer Verlag

ISER, W. 1970. Die Appelstruktur der Texte: Unbestimmtheit als Wirkungsbedingung literarischer Prosa. Konstanz: Universitatsverlag

JAUSS, HR. 1970. Literaturgeschichte als Provokation. Frankfurt : Suhrkamp.

KOHLER, W 1969. The Task of Gestalt Psychology. Princeton : University Press

LATEGAN, B.C. 1987. Inleidende opmerkings oor resepsieteorie en die uitleg van Bybelse materiaal Ned. Geref. Teologiese Tydskrif, 28(2):112-117.

LATEGAN, B C 1992 The Reception of Reception Theory in South Africa (In Lategan, B C, ed. The Reader and Beyond (HSRC Series in Methodology) Pretoria HSRC. p 1-12.)

LATEGAN, B C. \& VORSTER, W S. 1985. Text and Reality Aspects of Reference in Biblical Texts Philadelphia Fortress Press 
LOSEE, J. 1980. A Historical Introduction to the Philosophy of Science. Oxford : University Press.

MAREN-GRISEBACH, M. 1970 Methoden der Literaturwissenschaft Munchen : Francke Verlag.

MCKNIGHT, E. 1992. Can We Make Sense in the Aftermath of Reception Theory? (In Lategan, B.C, ed. The Reader and Beyond. (HSRC Series in Methodology) Pretoria : HSRC. p. 265-284)

MISCALL, P.D 1990 Jacques Derrida in the Garden of Eden Union Seminary Quarterly Review, 44:1-9.

MONTROSE, L. A 1989. Professing the Renaissance: The Poetics of Culture (In Veeser, H A. ed The New Historicism New York: Routledge p 15-36.)

MUILENBERG, J 1969. Form Criticism and Beyond. Journal of Biblical Literature, 88 118

NIELSEN, K 1990. Intertextuality and Biblical Scholarship. Scandinavian Journal for the Old Testament, 2:89-95

PRINSLOO, W S 1988 Die histories-kritiese metode(s) in perspektief. Skrif en Kerk, 9(2) 196-209

RJCHTER, W 1971. Exegese als Literaturwissenschaft Entwurf einer alttestamentlicher Literaturtheorie und Methodologie Gottingen : Vandenhoeck \& Ruprecht.

RICHTER, W 1978 Grundlagen einer althebraischen Grammatik St Ottilien : Eos Verlag

ROBERTS, J H. 1975 Wat behels 'n dinamies-ekwivalente vertaling? Ned. Geref. Teologiese Tydskrif, 16(3): 193-206.

ROBERTS, J.H 1981. Skriftuurlike grondslae vir ekumene Ned. (ieref. Teologiese Tydskrif. 22 (3) $188-200$

RUND, H 1962. The World View of Modern Theoretical Physics (Communications of the University of South Africa.) Pretoria UNISA

SCHOLES, R 1974. Structuralism in Literature New Haven. Yale University Press

SMITH, M 1971. Palestinian Parties and Politics that Shaped the Old Testament Columbia : University Press

SNYMAN, G.J. 1991 Biblical Hermeneutics and Reception Theory: The Authority of Biblical Texts and the Chronicler's Interpretation of the Sacred Story of the Ark Pretoria UNISA. (D Th-proefskrif.)

SNYMAN, G.J. 1992a. The Old Tesiament: An Absurd Fossil or a Pool in the Great Sea of Stories? ( $/ n$ Wessels, W J \& Scheffler, E H. ed Old Testament Science and Reality A Mosaic for Deist. Pretoria : Verba Vitae p 70-88.)

SNYMAN, G J 1992b The Theologian's Search for "Meaning": Restraint or Liberation of the Creative Spirit? Spil Plus, 22:111-123

SPITZER, L 1948. Linguistics and Literary Style Princeton: University Press

TOV, E. 1978 The Nature of the Hebrew Text Underlying the LXX A Survey of the Problem Journal for the Study of the Old Testamem, 7:53-68.

TOV, E 1982. A Modern Textual Outlook Based on the Qumran Scrolls Hebrew Union College Ammal, 53:11-27

VAN DER WOUDE, A.S 1985. Profeet en establishment Een verklaring van het boek Miga Kampen : Kok.

VAN NIEKERK, A 1992. Rasionaliteit en relativisme. Op soek na 'n rasionaliteitsmodel vir die Menswetenskappe (RGN-Studies in Metodologie.) Pretoria : RGN

VAN WOLDE, E 1990 Van tekst via tekst naar betekenis: Intertekstualiteit en haar implicaties Tijdschriff voor Theologle. 30:333-361

VAN ZYL, A H 1972 Literère vorme en eksegese Ned. (jeref. Teologiese Tydskrif, 13(3) 149-159. 
VAN ZYL, A H. 1973. Redaksiegeskiedenis en die prediking. Ned. Geref. Teologiese Tydskrif. 14(2):114-125.

VEESER, H.A ed. 1989. The New Historicism. New York : Routledge.

VERHOEF, P.A. 1973. Metodiek van eksegese Kaapstad: NG Kerk-Uitgewers.

WEINFELD, M 1972. Deuteronomy and the Deuteronomic School. Oxford : Clarendon Press

WEISS, M. 1961. Wege der neuen Dichtungswissenschaft in ihrer Anwendung auf die Psalmenforschung Biblica, 42:255-302.

WELLEK, R. \& WARREN, A 1968 Theory of Literature Middlesex : Penguin

WESSELS, J.P.H 1993. Die agtergeblewe nasies in die land 'n Teologiese ondersoek in Rigters 2:20-3:6. Pretoria : UNISA (D. Th-proefskrif)

WIENOLD, G 1972. Semiotik der Literatur. Frankfurt: Athenäum

WIMSATT, W K 1970. Battering the Object: The Ontological Approach. (In Bradbury, M. \& Palmer, D, ed. Contemporary Criticism. London : Edaward Arnold p. 61-81.) 